\title{
Facial Vascularized Composite Tissue Allotransplantation
}

\author{
Fatih Zor $\left(^{*}\right)$
}

\begin{abstract}
SUMMARY
Reconstruction of severe composite defects of the face is challenging for reconstructive surgeons. Despite several reconstructive techniques, the functional and aesthetic results of these patients are not acceptable. As a major organ, face, has an utmost importance in daily life. The specific characteristics of face require not a reconstruction, but a replace with same tissue. With the evolution of vascularized composite tissue allotransplantation, successful reconstruction of these defects became into reality. However, this new reconstructive option brings its new problems with it. Today, we are witnesses of evolution of reconstructive surgery to restorative surgery. In this article, this evolution is summarized.

Key words: Composite tissue allotransplantation, vascularized tissue allotransplantation, face transplantation

\section{ÖZET}

Fasyal Vaskülarize Kompozit Doku Allotransplantasyonu

Yüz bölgesinin kompleks kayıplarının onarımı rekonstrüktif cerrahlar için oldukça güçtür. Tanımlanan çeşitli onarım tekniklerine rağmen, bu hastalarda kabul edilebilir fonksiyonel ve estetik sonuçların alınması güçtür. Majör bir organ olarak yüz günlük yaşantımızda çok önemli bir yere sahiptir. Yüz bölgesinin kendine has karakteristik özellikleri nedeni ile, onarımdan ziyade restore edilmesine intiyaç vardır. Günümüzde, vaskülarize kompozit doku allotransplantasyonundaki gelişmeler ile birlikte yüz bölgesinin bu kayıplarının başarılı bir şekilde onarılması gerçekleştirilmiştir. Ancak, bu yeni onarım tekniği, beraberinde ek sorunlar da getirmiş̧ir. Bugün, hepimiz onarım cerrahisinin restorasyon cerrahisine evriminin birer tanığıyız. Bu makalede, bu evrim özetlenmektedir.
\end{abstract}

Anahtar kelimeler: kompozit doku allotransplantasyonu, vaskülarize doku allotransplantasyonu, yüz nakli

\footnotetext{
* Department of Plastic and Reconstructive Surgery, Gulhane Military Medical Academy and School of Medicine, Ankara, TURKEY

Reprint request: Dr. Fatih Zor, Department of Plastic and Reconstructive Surgery, Gulhane Military Medical Academy Ankara, TURKEY

E-mail: fatihzor@yahoo.com
}

\section{Introduction}

The face has an utmost importance as it plays a major role in an important role in a person's identity and communication. Besides its physiologic functions, it also has aesthetic, social and psychological functions. Facial skin has a unique character, which has a close anatomical and functional association with the underlying muscles and facial skeleton. Defects, arising from high-energy traumas, oncologic ablative surgeries or congenital anomalies may cause severe facial deformities and can have a significant functional impact on a patient's quality of life (1).

Combinations of standard skin grafting, application of local flaps, tissue expansion, prefabrication, and free tissue transfers $(2,3,4,5,6,7,8)$ are the well-established methods of current reconstructive procedures of facial deformity. Despite multiple surgical operations, the functional and aesthetic outcome of severe facial defects and deformities are not satisfactory in the long term follow-up since quite often the result is a masklike face with a lack of facial expression and an unsatisfactory cosmetic appearance. The best functional and aesthetic outcome of facial reconstruction was obtained following replantation of total face and scalp avulsion (9). This confirms that the only option for restoring facial features in severely disfigured patients remains transplantation of face.

Following thefirstsuccessfulhand transplantin France in 1998, vascularized composite allotransplantation (VCA) have opened up a new era in the reconstructive field (10). In 2004, The Cleveland Clinic Foundation's Institutional Review Board approved the world's first face transplantation protocol, which was presented by Dr. Maria Siemionow. Later, a French team led by Dr. Dubernard performed the first partial face transplantation of the world in 2005 (11). 
Face transplantation is now introduced as a treatment option for patients with severe facial disfigurements whose problem cannot be addressed by autologous tissues. Many studies were performed and published on the technical, immunosuppressive, and ethical issues of face transplantation with both in favor and against this challenging procedure (12).

\section{Conventional Reconstructive Methods}

The conventional reconstructive ladder for facial reconstruction includes skin grafts, local and distant flaps, prefabricated flaps, expanded flaps, and free flaps. Monoblock full thickness skin grafting has been successfully used for total facial resurfacing, however, the color, texture and quality of facial skin is hard to be obtained by this method in the long term (5). Prefabrication and tissue expansion can be used with success however, both have some disadvantages, especially during reconstruction of major facial defects $(2,3,7)$. Tissue expanders have the advantage of expanding the adjacent skin to achieve sufficient tissue of identical color and texture for facial reconstruction $(2,4)$. Unfortunately, in some cases, the adjacent skin is also partially or completely damaged, because of the initial trauma and the repetitive surgical procedures, making adequate reconstruction almost impossible.

With the advancement of the microsurgical techniques, different types of free tissues were transferred from distant parts of the body to reconstruct craniofacial deformities. Although various types of free flaps have been described and used for reconstructing the face, the functional and aesthetic results of severe defects and deformities has been suboptimal. Moreover, each autologous reconstructive procedure has a donor site morbidity of varying degrees.

Current methods of face reconstruction fail when tissue loss is considerable, because total resurfacing of the face with a single soft, pliable tissue, matched in color and texture, is almost impossible. Moreover, reconstruction facial muscles and skeleton causes additional problems. As a result, there is simply no conventional technique that addresses the reconstruction of facial soft and bony tissues and the final outcome after all these conventional reconstructive procedures is far from ideal. For this reason, craniofacial CTA promises to be the golden standard in craniofacial reconstruction (1).
2. Vascularized Composite Tissue Allotransplantation Vascularized composite tissue allotransplantation (VCA) involves the transplantation of tissues, derived from ectoderm and mesoderm. A VCA typically contains skin, fat, muscle, nerves, lymph nodes, bone, cartilage, ligaments, and bone marrow as opposed to solid organ transplantation (SOT). Limb transplantation is an excellent example of VCA, in which the transplanted graft includes skin, fat, muscle, nerves, bone, cartilage, ligaments, and bone marrow. The functional outcome of SOT is defined by physiologic properties of that specific organ. However, each tissue in VCA shows different functional and immunologic characteristics and the overall success of the VCA is a combination of all these functional outcomes. As a result, the indications of SOT are well defined and aim to restore the function of the organ and preserve life. However, most of the VCA applications do not preserve life but aim to improve the quality of life for a non-lifethreatening condition. Thus, indications of VCA are determined according to the balance between the functional gain at the expense of side effects of lifelong immunosuppression (13).

The first VCA was performed in 1963, but was rejected after only 3 weeks. The development of more effective immunotherapy made VCA a reality (14). The first successful VCA is performed in 1998 and later in 2005, Dr. Dubernard performed the first partial face transplantation. The skin is known to be the most antigenic tissue of the body and which makes immunology an important part of VCA $(10,11)$.

The facial VCA came into reality following experimental and cadaveric studies and all these studies provided enough know-how of face transplantation (15).

\section{Experimental Models of Facial VCA}

During the last 20 years many facial VCA models were developed for testing feasibility of transplantation of different facial components and for testing effects of various immunosuppressive protocols. The experimental models can be divided into two main categories: Small and large animal models.

Small animal models: The first facial VCA model was full-face, scalp transplant model and described by Ulusal et al (16). In this model, the entire facial skin 
and scalp flap including both ears were transplanted, based on the bilateral common carotid arteries and external jugular veins (Figure 1). Later, hemiface

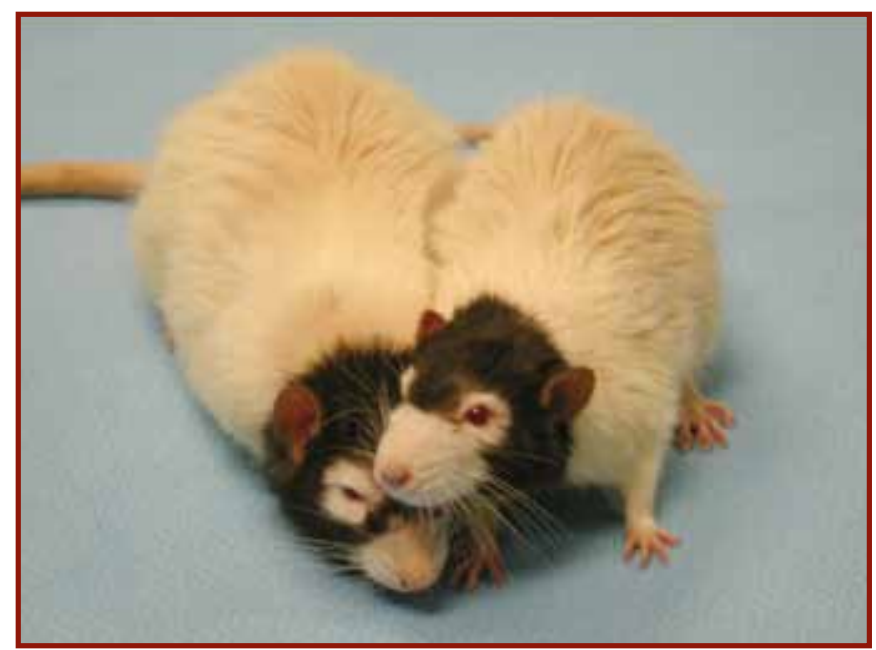

Figure 1. Full-face transplant model, allotransplantation was performed between LBN and Lewis rats.

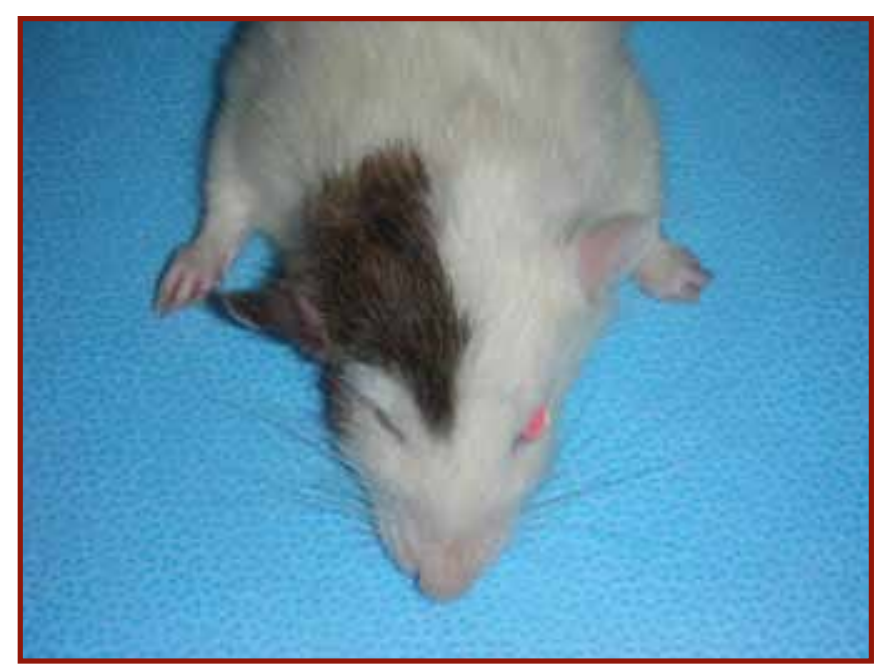

Figure 2. Hemiface transplant model, allotransplantation was performed between LBN and Lewis rats.

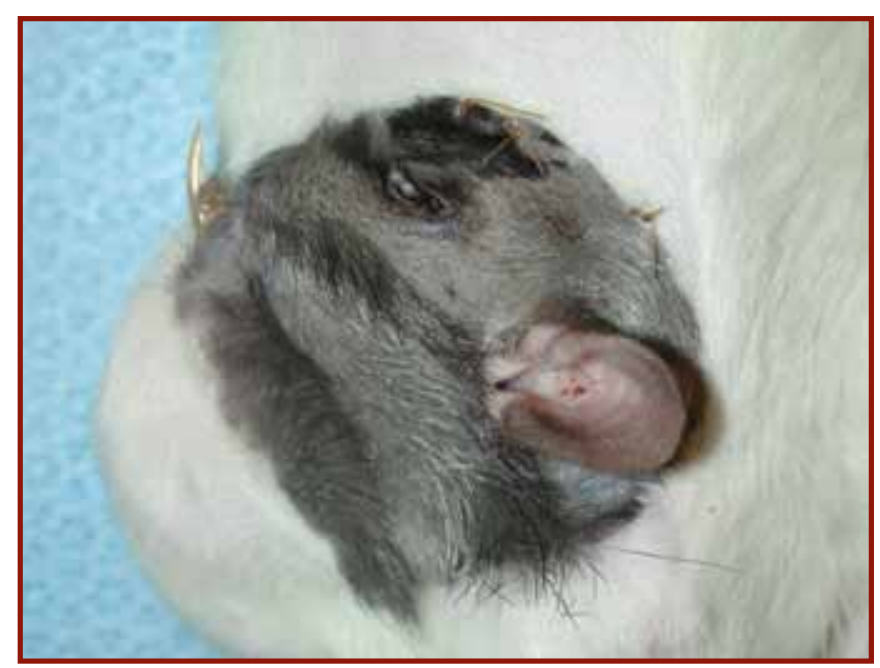

Figure 3. Hemiface tongue, mandible model, allotransplantation was performed between $\mathrm{ACl}$ and Lewis rats. transplant model was developed (17) which included hemifacial skin and scalp including ear (Figure 2). Composite hemiface calvarium transplantation model was developed by including calvaria to the hemiface transplant model by Yazıcı et al (18). In Maxilla Allotransplantation Model, maxilla were dissected along Le-Fort II osteotomy lines based on the common carotid artery and external jugular vein and transplanted (19). The development of facial VCA was widened by including different facial tissues. Composite hemiface, mandible, tongue osteo-musculocutaneous flap model was developed by Kulahci et al $(20,21)$. This model included almost all tissue type of the face including the bone marrow (Figure 3). Later, the first facial transplantation model including motor and sensorial units was described by Zor et al. (22). This model (Composite midface transplant model with sensory and motor neuromuscular units) included midfacial structures and premaxilla including facial and infraorbital nerves (Figure 4). Total hemiface allotransplantation model was developed by Altuntas et al (23). Recently, composite eye transplantation model was developed by Polat et al (24).

Large animal models: Facial transplantation models in large animals were included Dog Hemifacial Transplant Model, Hemifacial Transplantation Model in Rabbits, Swine Model of Hemi-Facial Composite Tissue Allotransplantation, Heterotopic Primate Model for Facial Composite Tissue Transplantation and Facial Subunit Composite Tissue Allografts in Nonhuman Primates $(25,26,27,28,29)$.

\section{Preparation for Facial Allograft Transplantation in Humans}

The success in experimental models has stimulated the development of cadaveric models in humans.

Full Face Transplant Models: In this model, the technical feasibility of face transplantation was tested. The entire face and scalp including the external ears was harvested based on the external carotid arteries and external jugular and facial veins. Vascular architecture was shown by methylene blue injection and the total surface of the flap was measured (30). Later, a mock facial transplantation was performed in order to determine the time for transplantation, best sequence of flap inset and anchoring procedure (31). Later, coronal-posterior approach, for facial/ scalp flap harvesting was described. Using coronal- 
posterior approach, an extended length of sensory nerves within the facial flap and reduced surgery time were obtained (32).

The plane of the facial flap harvest was first studied by Baccarani et al. They described two different planes. In first technique, the skin and soft tissue of the face was harvested by dissections carried in a subgaleal, sub-SMAS, and subplatysmal planes. In second technique, the entire soft tissue and bony structures of the midface were harvested by a subperiosteal plane dissection combined with a Le Fort III osteotomy. This study showed that both planes could be used reliably in facial flap harvest (33).

Partial Face Transplant Models: Under the apparent continuity of its form and contours, the face can be surgically divided into distinct anatomic units. According to these anatomic principles, there are three main segmental facial allografts that can be harvested from one or more branches of the external carotid arterial network. Lower central facial allograft includes the nose, lips and chin. This flap is vascularized by two facial vessels; the perioral muscles are included in the flap with sub-periosteal dissection. Motor nerves of the perioral muscles, mental and infraorbital nerves are included in the flap. Midfacial allograft includes the nose, upper lip, cheeks and perioral muscles. Facial vessels, fascial nerve and infraorbital nerve consists the pedicle of the flap. Upper facial allograft contains the forehead, eyelids and the root of the nose including the periorbital muscles. Superficial temporal vessels, zygomatic branch of facial nerve and supraorbital nerve consists the pedicle of the flap (34).

\section{Clinical Application of Craniofacial Allotransplantation:}

The success in both experimental/cadaveric facial transplantation models and clinical applications of CTA has stimulated the application of facial transplantation in humans.

On 27 November 2005, in Amiens, France; a surgical team led by Dr Devauchelle and Dr Dubernard announced that they had performed a partial face transplant on a 38-year-old female, whose face has been disfigured by a dog bite (11). The postsurgical induction immunosuppression protocol included thymoglobulins combined with tacrolimus, mycophenolate mofetil, and prednisone.

Later, several face transplantations were performed in China, USA, Spain, and Turkey. The first near total face transplant was performed by by a group led by Dr. Maria Siemionow from Cleveland Clinic, in 2008. This face transplant was also the first osteocutaneous face transplant of the world (35).

Cleveland Clinic Experience: The patient was a 45-year-old woman sustaining from a severe facial trauma to her midface from a close-range shotgun blast. The initial examination revealed a three dimensional defect including nose, nasal lining and underlying bone with contracted remnants of the upper lip, loss of oral and ocular muscle functions. The patient was comprehensively assessed by a multi-disciplinary team of specialists, including plastic surgeons, otolaryngologists, transplant surgeons, anesthesiologists, transplant psychiatrists, bioethicists, dentists, transplant infectious-disease specialists, and immunologists. The donor was a brain-dead woman with a similar age, race, and skin complexion to the recipient.

The scarred and contracted tissue at the midfacial region of the recipient was all removed including previous soft and bone tissues and actual tissue defect is determined. The composite tissue allograft, composed of nearly $80 \%$ of the surface area of the anterior craniofacial skeleton, was harvested based on bilateral common facial arteries, external jugular veins and left posterior facial vein. Anterior maxilla with incisors was included in the graft by a Le Fort III osteotomy.

The graft was composed of nose, lower eyelids, upper lip, total infraorbital floor, bilateral zygomas, and anterior maxilla with anterior hard palate, and bilateral parotid glands. Following the harvest, graft was transferred to the recipient for the final inset. Bony fixation, vascular anastomoses and nerve repairs were performed (Figure 5).

Anti-thymocyte globulin and methylprednisolone were used as induction therapy and immunosuppressive regimen was maintained with tacrolimus, mycophenolate mofetil, and low-dose oral prednisone.

Monitorization was performed with complete blood count, lymphocyte ATP function evaluation, tacrolimus level measurement, and mucosa and skin biopsies. Physiotherapy, speech therapy and psychological support were also provided.

\section{Immunological issues:}

There is well-known that the most challenging part of composite face allotransplantation is the 


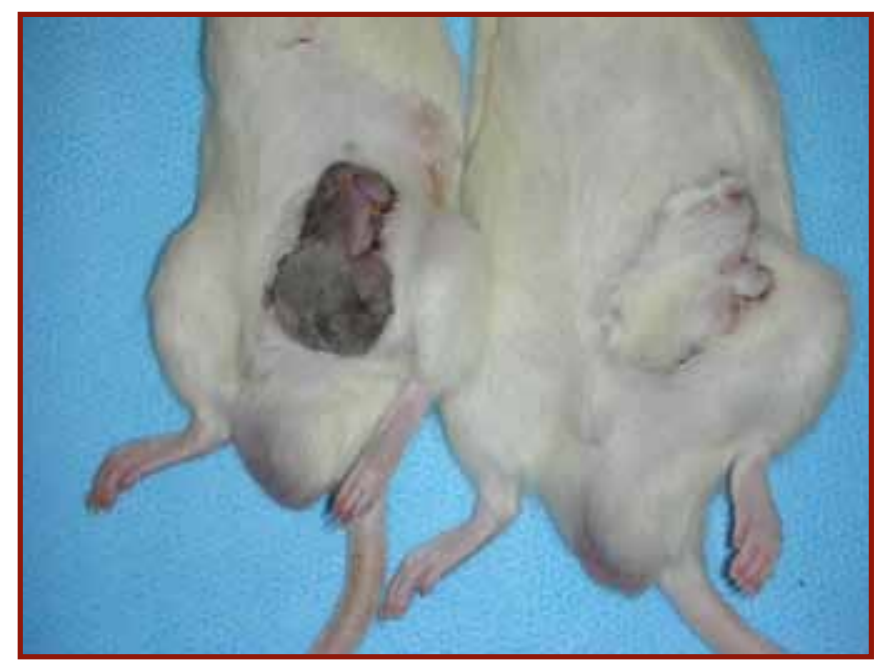

Figure 4. Midface transplantation model with sensorial and motor units, allotransplantation (left) and isotransplantation (right)

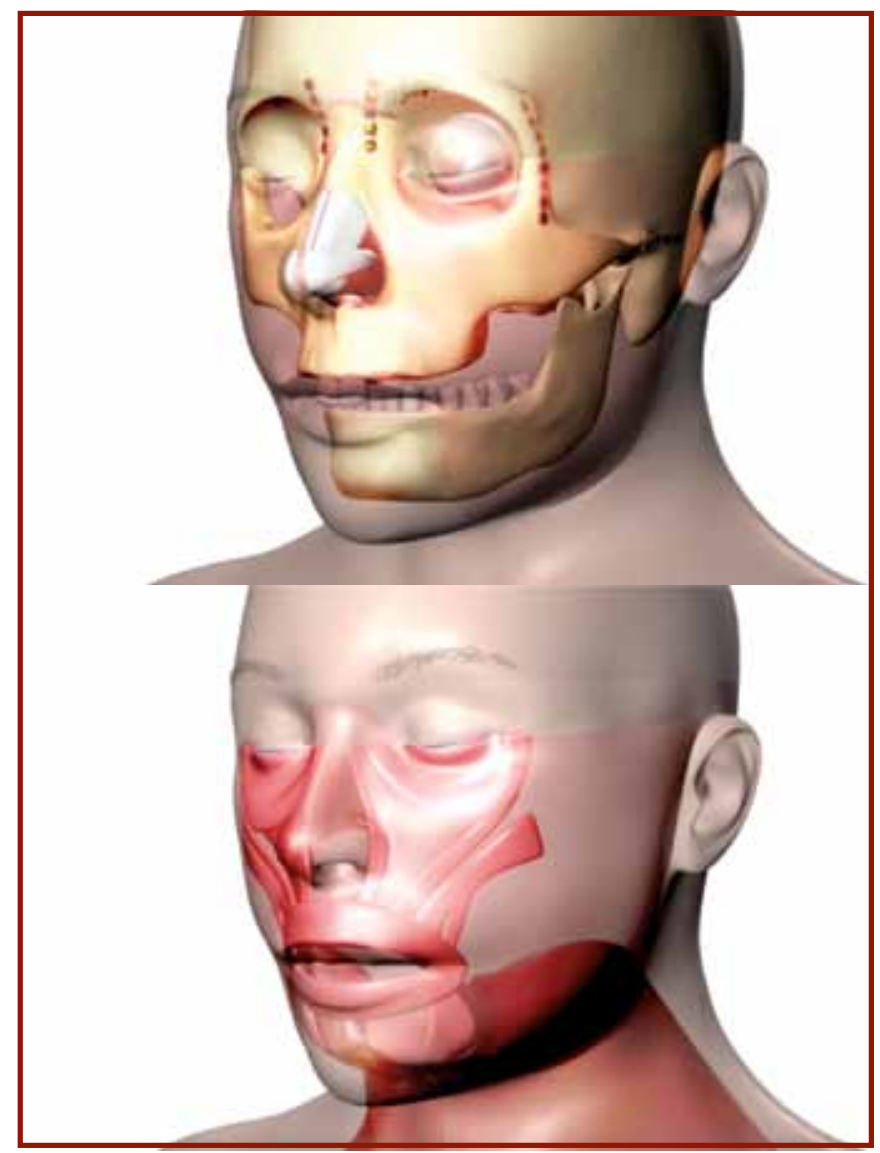

Figure 5. (A) Facial transplantation, note that maxilla, bilateral zygoma, and whole nose are included (B) The transplanted muscles and skin of the World's first near total face transplant.

prevention of rejection. Today, the only way to prevent graft rejection is chronic immunosuppression and there are several drugs and protocols which are used experimentally and clinically. However, the ultimate goal of transplant immunology is to provide donor specific tolerance.
Immunosuppressive treatment can currently be divided into three phases: induction, maintenance, and rescue therapies. Induction immunotherapy is used as a means to overcome the ischemic injury and surgical trauma an allograft undergoes during the transplant process. The surgery creates an immunogenic organ that is more susceptible to immunologic attacks. The purpose of induction therapy therefore is to sufficiently suppress recipient immune responses. Maintenance therapy is defined as immune suppression that is typically much lower in dose than induction therapy and therefore applicable in a chronic setting. Rescue therapy is similar to induction therapy in that it employs highdose immune suppression and is usually instigated in response to a rejection episode.

Besides immunosuppressive therapies, some additional measurements are needed to prevent rejection of the graft. Of those, perhaps the most important one is matching donor and recipient. Compatibility for major blood groups (ABO) and a negative crass-match is essential. Matching for HLA antigens is beneficial in VCA so if possible 3 or more HLA match would be beneficial (36). Despite the administration of immunosuppression, several rejection attacks may be observed during the follow up of the patient. The rejection in VCA is primarily a cell-mediated immune response.

Itisknown that, usage of lifelongimmunosuppressive agents to prevent rejection is a must for all patients who receive a transplant. In facial transplantation, the main target of the rejection is the skin and thus the acute rejection attack can be determined in earlier stages by observation and biopsies.

Chronic immunosuppressive therapy has wellknown side effects and may give rise to conditions that shorten life. As the face transplantation is not a life saving procedure like solid organ transplantation, the risks of immunosuppression should not be underestimated. The immunosuppressive agents that are used currently may cause serious agent-specific side effects that may include hypertension, renal toxicity, diabetes, and disturbances in blood lipid levels, and these effects are generally dose-dependent. Long-term immunosuppression also increases the risk of infection and cancer (37). As a result, ultimate goal of transplantation research is to develop donorspecific immunological tolerance against a graft (38). There are various strategies that are being studied 
for obtaining donor-specific immunological. Of those, transplantation of donor bone marrow cells or stem cells is most widely used (11). These strategies provide hematopoietic stem cell (HSC) chimerism. In chimerism, tissues from two genetically distinct organisms co-exist in one organism (39). However, additional studies are needed for creation of donorspecific tolerance.

\section{Psychological, Social and Ethical Considerations:}

Recent applications of composite tissue allotransplantation (CTA) in facial reconstruction opened new ethical and social debates. Of primary interest is discussion on weighing risk posed by the lifelong immunosuppression required to prevent rejection as opposed to the benefit of receiving a new face. Researches have shown different levels of risk acceptance of CTA procedures, based on psychosocial dynamics involved in facial disfigurement.

At the center of these discussions have been issues such as post-transplant quality of life and life expectancy as well as patient preference and risk acceptance for these experimental procedures. The fundamental argument has centered on the ideological differences between the risks individuals are willing to accept to receive a "life-saving" morbidity-reducing treatment versus a "nonlifesaving" quality-of-life-enhancing treatment $(40,41)$. The risks due to immunosuppressive treatment include life-threatening infections, new onset diabetes, cancers, and organ damage. The patients would be also suffering from psychological trauma. Thus, There is an agreement that a multidisciplinary team of experts should evaluate potential candidates for face transplantation. The proponents of facial transplantation emphasized that the rights of patients with severe facial deformities to improve their quality of life should be included in any discussion on facial transplantation and the suffering of patients with severe facial disfigurement must be recentered in the public ethical discussions (42). On the other side, opponents of transplantation procedure have raised the issue of the consequences of facial flap rejection. The psychological consequences of graft rejection will be enormous and that issues related to facial identity are considered an important ethical contraindication $(40,41)$.

Another ethical issue arises in terms of donor related concerns. In most societies, despite different culture and religion, great respect is paid to the body of deceased person. This is needed for traditions and rituals for the gateway to "life after death". Procuring tissue from a deceased donor presents numerous concerns. These include dignified treatment of the deceased, donative decision-making, and the psychological impact on families and relatives of the donor due to the visual and intimate aspect of the donor facial tissue.

\section{Future perspectives and conclusions}

Face transplantation has been shown thus far to be a viable option in some patients suffering severe facial deficits, which are not amenable to modern-day reconstructive techniques. As newer immunosuppression options such as donor specific tolerance become available, indications for face transplantation will be greatly expanded. Future research in regards to the ethical and psychological challenges complicating the identification of the optimal face transplant candidate, establishing effective face transplant rehabilitation protocols, and expanding large animal immunologic basic science investigation, is undoubtedly warranted (43).

\section{References:}

1. Siemionow M, Sonmez E. Face as an organ. Ann Plast Surg 2008;61: 345-352.

2. Boyd JB. Tissue expansion in reconstruction. South Med J 1987; 80:430-432.

3. Erol OO. The transformation of a free skin graft into a vascularized pedicle flap. Plast Reconstr Surg 1976; 58:470-477.

4. Kawashima T, Yamada A, Ueda K, Asato H, Harii K. Tissue expansion in facial reconstruction. Plast Reconstr Surg 1994; 94:944-50.

5. Latifoglu O, Ayhan S, Atabay K. Total face reconstruction: skin graft versus free flap. Plast Reconstr Surg 1999; 103:1076-1078.

6. McIndoe AH. Total reconstruction of the burned face. The Bradshaw Lecture 1958. Br J Plast Surg 1983; 36:410-420.

7. Pribaz JJ, Fie N, Orgill DP. Flap prefabrication in the head and neck a 10-year experience. Plast Reconstr Surg 1999; 103:808-820.

8. Teot L, Cherenfant E, Otman S, Giovannini UM. Prefabricated vascularised supraclavicular flaps for face resurfacing after postburns scarring. Lancet 2000; 355:1695-1696.

9. Wilhelmi BJ, Kang RH, Movassaghi K, Ganchi PA, Lee WP. First successful replantation of face and scalp with single-artery repair: model for face and scalp transplantation. Ann Plast Surg 2003; 50:535-540. 
10. Dubernard JM, Owen E, Herzberg G, Lanzetta M, Martin X, Kapila H, Dawahra M, Hakim NS. Human hand allograft: report on first 6 months. Lancet 1999; 353: 1315-1320.

11. Devauchelle N, Badet L, Lengele B, Morelon E, Testelin S, Michallet M, D'Hauthuille C, Dubernard JM. First human face allograft: early report. Lancet. 2006; 368: 203-209.

12. Lengele BG. Current concepts and future challenges in facial transplantation. Clin Plast Surg. 2009;36:507521.

13. Siemionow MZ, Kulahci Y, Bozkurt M. Composite tissue allotransplantation. Plast Reconstr Surg 2009;124(6 Suppl):e327-39.

14. Gander B, Brown CS, Vasilic D, Furr A, Banis JC Jr, Cunningham M, Wiggins O, Maldonado C, Whitaker I, Perez-Abadia G, Frank JM, Barker JH. Composite tissue allotransplantation of the hand and face: a new frontier in transplant and reconstructive surgery. Transpl Int. 2006; 19: 868-80.

15. Kulahci Y, Bayram Y, Karagoz H, Sever C, Sahin C. Experimental Craniofacial Composite Tissue Allotransplantation (CCTA) Models in Rats. Arch Clin Exp Surg. 2012; 1(3): 181-187.

16. Ulusal BG, Ulusal AE, Ozmen S, Zins JE, Siemionow MZ. A new composite facial and scalp transplantationmodel in rats. Plast Reconstr Surg 2003; 112:1302-1311

17. Unal S, Agaoglu G, Zins J, Siemionow M. New surgical approach in facial transplantation extends survival of allograft recipients. Ann Plast Surg 2005; 55:297-303.

18. Yazici I, Unal S, Siemionow M. Composite hemiface/ calvaria transplantation model in rats. Plast Reconstr Surg 2006;118:1321-1327.

19. Yazici I, Carnevale K, Klimczak A, Siemionow M. A new rat model of maxilla allotransplantation. Ann Plast Surg 2007;58:338-344.

20. Kulahci Y, Siemionow M. A new composite hemiface/ mandible/tongue transplantation model in rats. Ann Plast Surg. 2010 Jan;64(1):114-21.

21. Kulahci Y, Klimczak A, Madajka M, Altuntas S, Siemionow M. Long-term survival of composite hemiface/mandible/tongue allografts correlates with multilineage chimerism development in the lymphoid and myeloid compartments of recipients. Transplantation. 2010 Oct 27;90(8):843-52.

22. Zor F, Bozkurt M, Nair D, Siemionow M. A new composite midface allotransplantation model with sensory and motor reinnervation. Transpl Int 2010; 23:649-656.

23. Altuntas SH, Zor F, Siemionow M. Total osteocutaneous hemiface allotransplantation model in rats. Plast Reconstr Surg 2010;6S:117.

24. Polat M, Zor F, Kurt B, Ors F, Battal B, Isik S. Evaluation of optic nerve regeneration on composite Face and Eyeball Allotransplant Model. Paper presented at Annual Meeting of the Turkish Society of Plastic, Reconstructive and Aesthetic Surgeons. September 14-18, 2011, Cesme-Izmir, Turkey.
25. Bermudez LE, Santamaria A, Romero T, Romero T, Calderó DF. Experimental model of facial transplant. Plast Reconstr Surg $2002 ; 110: 1374$.

26. Xudong Z, Shuzhong G, Yan H, Datai W, Yunzhi N, Linxi Z. A hemifacial transplantation model in rabbits. Ann Plast Surg. 2006 Jun;56(6):665-9.

27. Kuo YR, Shih HS, Lin CC, Huang CC, Yang JC, Wu WS, Goto S, Chen CL, Lee WP. Swine hemi-facial composite tissue allotransplantation: a model to study immune rejection. J Surg Res. 2009 May 15;153(2):268-73.

28. Silverman RP, Banks ND, Detolla LJ, Shipley ST, Panda A, Sanchez RA, Azimzadeh AM, Pierson RN 3rd, Wang D, Rodriguez ED, Holton LH 3rd, Bartlett ST. A heterotopic primate model for facial composite tissue transplantation. Ann Plast Surg. 2008 Feb;60(2):20916.

29. Barth RN, Bluebond-Langner R, Nam A, Stanwix M, Shipley S, Bartlett ST, Rodriguez ED. Facial subunit composite tissue allografts in nonhuman primates: I. Technical and immunosuppressive requirements for prolonged graft survival. Plast Reconstr Surg. 2009 Feb;123(2):493-501.

30. Siemionow $M$, Kulahci Y. In preparation for facial transplantation. In: Eisenmann-Klein M, NeuhannLorens C (eds.) Innovations in Plastic and Reconstructive Surgery. Springer-Verlag Berlin Heidelberg, Germany, 2008;150-159.

31. Siemionow M, Bozkurt M, Kulahci Y. Current status of composite tissue allotransplantation. Handchir Mikrochir Plast Chir 2007;39:145-155.

32. Siemionow M, Papay F, Kulahci Y, Djohan R, HammertW, Hendrickson M, Zins J. Coronal-posterior approach for face/scalp flap harvesting in preparation for face transplantation. J Reconstr Microsurg 2006; 22:399-406.

33. Baccarani A, Follmar KE, Baumeister SP, Marcus JR, Erdmann D, Levin LS. Technical and anatomical considerations of face harvest in face transplantation. Ann Plast Surg. 2006 Nov;57(5):483-8.

34. Lengele BG. Current concepts and future challenges in facial transplantation. Clin. Plast. Surg. 2009; 36: 507521.

35. Siemionow M, Papay F, Alam D, Bernard S, Djohan R, Gordon C, Hendrickson M, Lohman R, Eghtesad B, Coffman K, Kodish E, Paradis C, Avery R, Fung J. Near-total human face transplantation for a severely disfigured patient in the USA. Lancet. 2009; 374:203-9.

36. Ceppellini R, Mattius PL, Scudeller G, Visetti M. Experimental allotransplantation in man. I. The role of HL-A system in different genetic combinations. Transplant Proc 1969; 1: 385.

37. Auchincloss H. In search of the elusive holy grail: the mechanisms and prospects for achieving clinical transplantation tolerance. Am J Transplantation 2001; 1: 6 . 
38. Siemionow M, Demir Y, Mukherjee AL, Klimczak A. Development and maintenance of donor-specific chimerism in semi-allogenic and fully major histocompatibility complex mismatched facial allograft transplants. Transplantation 2005; 79: 558.

39. Burlingham WJ: Chimerism after organ transplantation: is there any clinical significance? Clin Transplant 10:110, 1996.

40. Butler PEM, Clarke A, Ashcroft RE. Face transplantation: when and for whom? Am J Bioethics 2004; 4:16-17.
41. Wiggins OP, Barker JH, Martinez S, Vossen $\mathrm{M}$, Maldonado C, Grossi F, Francois C, Cunningham M, Perez-Abadia G, Kon M, Banis JC. On the ethics of facial transplantation research. Am J Bioeth 2004; 4:1-12

42. Agich GJ, Siemionow M. Facing the ethical questions in facial transplantation. Am J Bioethics 2004; 4:25-27

43. Siemionow MZ, Zor F, Gordon CR. Face, upper extremity, and concomitant transplantation: potential concerns and challenges ahead. Plast Reconstr Surg 2010;126:308-315. 